\title{
EXAMINING A SPEAKING SYLLABUS AT TERTIARY LEVEL
}

\author{
Susiati \\ Program Studi Pendidikan Bahasa Inggris \\ Fakultas Keguruan dan Ilmu Pendidikan \\ Universitas Muhammadiyah Surakarta \\ sus249@ums.ac.id
}

\begin{abstract}
This study examines how a Speaking syllabus at tertiary level meets the students' needs through debating activity. Employing Brown's (1995) and Richards' (2001) theories as the main stake, six elements of the syllabus have been investigated that are needs analysis, objectives, language learning philosophy, methodology, materials used and resources and evaluation. It has been found that some revisions of the syllabus are needed to satisfy the Department's vision that prepares the students to be English teachers. However, both debating materials and activities seem to be useful for improving the students' critical thinking. Of all the elements, material resources are considered the weakest part of the syllabus since it provides less appropriate references.
\end{abstract}

Keywords: Speaking syllabus, English, tertiary level, debating acitivity

\section{ABSTRAK}

Penelitian inimengkaji bagaimana silabi mata kuliah Speaking pada tingkatperguruan tinggi memenuhi kebutuhan kemampuan berbicara siswa melalui kegiatan debat. Enam elemen silabi yaitu analisis kebutuhan, tujuan, filosofi pembelajaran bahasa, metode, materi dan sumber materi dan evaluasi dianalisis dengan menggunakan teori Brown (1995) dan Richards (2001) untuk analisis utama. Hasil temuan kajian menunjukkan bahwa revisi pada beberapa bagian silabi diperlukan untuk mencapai visi program studi untuk menyiapkan para calon guru bahasa Inggris. Namun, baik materi maupun kegiatan debat dapat meningkatkan kemampuan berpikir kritis siswa. Dari semua elemen, sumber materi merupakan bagian yang dianggap paling lemah perencanaannya karena referensi yang digunakan kurang layak.

Kata Kunci: Silabi mata kuliah Speaking, bahasa Inggris, perguruan tinggi, kegiatan debat

\section{INTRODUCTION}

"A syllabus is a specification of the content of a course of instruction and lists what will be taught and tested" (Richards, 2001:1). A syllabus should be appropriate with the overall curriculum (Celce-Murcia \& Olsthain, 2000) and meet the students' needs (Hall \& Cook, 2011). Brown (1995) remarks that there are at least five elements involved in designing a syllabus: needs analysis, objectives, teaching or methodology, materials used, and testing or evaluation. In this study, I will add language learning philosophy before the methodology because it seems important to know the theory of language learning prior to decide what methodologies used to teach the materials.

However, a question arises: may these elements not satisfy students' needs? I will answer this question by examining a syllabus of speaking course in my teaching and learning context. 
This course is given to the third semester students of tertiary level in the Department of English Education which focuses on discussion and debate activities. Since this department is under School of Teacher Training and Education, most of the students enrol this department to expectedly become English teachers, and this is compatible with the school's vision that is to create professional teachers (FKIP UMS, 2015). I will discuss whether the syllabus elements meet the students' needs. Although the syllabus encourages critical thinking and helps students adapt to $21^{\text {st }}$ century thinking, some aspects of the syllabus are not appropriate and do not meet the students' needs.

In this research, I will discuss these strong and weak aspects of the syllabus on the needs analysis, objectives, language learning philosophy, methodology, materials used, and evaluation in the discussion section. Most of the elements' terms in the syllabus are different from those suggested by Brown, indicators instead of objectives, learning experiences instead of methodology and teaching materials instead of materials used. Not to confuse, I will consistently use Brown's terms. The changes that could be made for the syllabus betterment are also provided. In the conclusion section, I will provide the summary of my stance and the changes that could be made.

\section{METHODS}

This qualitative study employs document review (Elmusharaf, 2012) of a Speaking syllabus. The document reviewed belongs to my teaching context that is at tertiary level used for teaching Speaking course. Content analysis is adopted to investigate some elements of the syllabus that are the needs analysis, objectives, language learning philosophy, methodology, materials used and evaluation as mainly proposed by Brown (1995) and Richards (2001).

\section{FINDINGS AND DISCUSSION}

\section{Needs Analysis}

Needs refer to wants, desires, demands, motivations, lacks, constraints, and requirements (Brindley, 1989) that, in a language learning, relate to linguistic deficiency describing what a student can do at present and what he or she should be able to do (Richards, 2001). A process of gathering these needs information, interpreting it and making it for a course decision is called needs analysis (Brown, 1995) or Graves (2000) calls it needs assessment. In this study, I will consistently use needs analysis. Furthermore, needs are stated in terms of goals and objectives (Hutchinson \& Waters, 1987; Brown, 1995). Specific discussion on objectives will be provided in the next sub-section. Therefore, this sub-section will focus on goals to analyse the needs. 


\begin{tabular}{ll}
\hline \multicolumn{2}{c}{ SPEAKING 3 (DISCUSSION AND DEBATE) SYLLABUS } \\
\cline { 2 - 2 } Study Program & \multicolumn{1}{c}{ COURSE OUTLINE } \\
Course Code & $: 3082020$ \\
Course & $:$ Speaking 3 (Discussion and Debate) \\
Credit hours & $: 2$ \\
Pre-requisite Course & $:$ Speaking 2 (Situational Communication) \\
Post-requisite Course & $:$ Speaking 4 (Presentations) \\
Semester & $:$ Three \\
\hline & \\
\hline
\end{tabular}

This course is designed to help the students to express ideas spontaneously in discussion and debate. The students introduced to various expressions commonly used in discussion and debate. The students are also given the opportunity to practice various debate system such as Australasian, Asian and British parliamentary system.

\section{Standard Competency:}

The students are able to:

1. use the appropriate expressions required in discussion and debate

2. acquire skills in discussion and debate

3. express ideas smoothly

4. understand different rules in various debating systems participate actively using different debating systems

The syllabus was arranged for Speaking course in semester 3 focusing on discussion and debate. The pre-requisite course is situational communication in Speaking 1 (taught in semester 1) and the post-requisite course is about presentation in Speaking 4 (taught in semester 4). The goals, which are mentioned in the standard competency, are in order the students are able to use the appropriate expressions required in discussion and debate, acquire skills in discussion and debate, express ideas smoothly, understand different rules in various debating systems and participate actively using different debating systems.

There are three points that are important to highlight regarding the needs analysis. First, this course seems not match the School's vision that is to create professional teachers (FKIP UMS, 2015). Discussion may be appropriate, but debate using Australasian, Asian and British parliamentary systems are more proper for professional debaters. Second, this course appears not to be in line with the pre and post courses' needs. Pre-course module is about situational communication such as communication at the bank, at the market, while the post-course module is about presentation such as speech, presenting others' academic writing. Discussion and debating activity needs high level of critical thinking and more challenging than the presentations. It is also a bit not a smooth move from situational communication to discussion and debate. Whereas, in designing a set of syllabus, gradation on level of difficulty is highly considered (Nunan, 1993). Third, however, discussion and debating activities encourage the students to think critically. These activities are good given to tertiary level students because debate and interpersonal communication skills are two factors that can successfully face the $21^{\text {st }}$ century challenges (Cator, 2011). 
This syllabus has strong and weak aspects at once. I will support this course still taught at the Department since discussion and debating activities are strategic ways to build the students' critical thinking. Although the debating systems seem not meet the School's vision, tertiary level students need this in order to face the $11^{\text {st }}$ century challenges (Cator, 2011). Candidate teachers' knowledge should not be limited on linguistic and teaching methodological matters, but they are also able to solve problems through discussing and debating the topics given in the classroom. In addition, if I were in a position make a change, regarding Richards' (2001) idea about the gradation of the level of difficulty, I will put this course at the end of the syllabus continuum. Discussion and debating skills seem more difficult in terms of critical thinking and language proficiency than those of situational communication and presentations. Moreover, I will use the term either standard competency or basic competency because it seems that the basic competency list promptly reflects on the standard competency.

\section{Objectives}

"Objectives are statements about how the goals will be achieved" (Graves, 2000: 76). Objectives are made to elaborate goals as the learning instructions (Fisher, 1996). Brown (1995) prefers to describe these as instructional objectives which mean "specific statements that describe the particular knowledge, behaviours, and/or skills that the learner will be expected to know or perform at the end of a course or program" (p.73). Therefore, objectives are more specific than goals, and the specificity does not depend on the word length made (op cit). Mager (1975: 13) suggests the following three characteristics of specific objectives:

a. Performance (what the learner will be able to do)

b. Conditions (important conditions under which the performance is expected to occur)

c. Criterion (the quality or level of performance that will be considered acceptable).

\begin{tabular}{|c|}
\hline OBJECTIVES \\
\hline Students are able to : \\
\hline $\begin{array}{l}\text { 1. Identify the appropriate expressions for asking for and providing meaning and clarification, } \\
\text { asking about/expressing opinions, giving commentary, getting people's attention and } \\
\text { interrupting, checking understanding/clearing up misunderstanding }\end{array}$ \\
\hline Chairing a discussion and meeting \\
\hline Speak fluently and confidently using the expressions learned \\
\hline Identify the technique of debating \\
\hline Explain the technique of debating \\
\hline Present an argument effectively \\
\hline Identify the rules in different debating system \\
\hline Explain the differences of various debating systems \\
\hline $\begin{array}{l}\text { 9. Participate actively and effectively in debate session using Australasian parliamentary } \\
\text { system, British parliamentary system, Asian parliamentary system }\end{array}$ \\
\hline
\end{tabular}

Seen from the objectives, the type of this syllabus is functional syllabus (Brown, 1995). This is called so because the objectives focus on "semantic uses" (McKay, 1978) such as "asking for and providing meaning and clarification, asking about/expressing opinions, interrupting". The objectives are divided into two separate phases. The first half semester (meetings 1 to 7) is for discussion activities, and the second half one (meetings 8 to 14) is for debating activities. The order is arranged from theory to practice in each discussion and debate. "Identify the appropriate expressions..." is theoretical, while "speak fluently and confidently 
using the expressions learned" is practical. In addition, several objectives break down one or two goals in this syllabus, except one last objective that generates one goal.

While some parts of the objectives are appropriate, other parts are not. The objectives are elaborated in detail and mostly reflect on the goals. The objectives order of the overall meetings that discussion comes before debate is appropriate since discussion appears to be easier than debate. However, I will suggest that the lecturers should not dichotomize the two because discussion is one process in debating activity (Kemdiknas, 2010). However, the all objectives do not satisfy the Mager's three essential characteristics of objectives. In the first half semester, the objectives only show the performances that the students are expected to be able to do. In the second half semester, it describes the performance and conditions expected to occur. What is lack in this syllabus is the criterion in what level of the expressions or activities considered acceptable. Furthermore, in meetings 8 to 14, the objective does not reflect on the goal. The goal is "to understand various debating systems". The word "to understand" tends to be theoretical, while the objective that is "participate actively and effectively in debate session..." sounds practical.

It needs to maintain the strengths of the objectives, while the drawbacks should be mended. I suggest that the objectives are better following the Mager's (1975) three essential characteristics of objectives: performance, conditions and criterion. For example, it will be great to add the criterion in the objective of the second half semester. I will add matter, manner and method because these are the standardized aspects assessed in Australian, British and Asian parliamentary systems (Kemdiknas, 2010; Depdiknas, 2010). Therefore, the quality to achieve by the students is clear. In addition, the three debating systems are not given in a meeting at once. Hence, each system should be given in separate meetings and elaborated more detail in the second half semester. Finally, I will exchange the goal positions of "to debate effectively" in meeting 7 and "to understand various debating systems" in meetings 8 to 14 with the reason of appropriateness as I have mentioned in the previous paragraph.

\section{Language Learning Philosophy}

Language learning philosophy used in this syllabus is communicative approach because of its functional syllabus type (Savignon, 1991) and Speaking course. The communicative needs of students are implied in the goals which develop the selection of methods and materials (op cit; Richards, 2001). Berns (1990:104) provides some of principles of Communicative Approach or CLT (Communicative Language Teaching) as follows:

a. Language teaching is based on a view of language as communication. That is language is seen as a social tool that speakers use to make meaning; speakers communicate about something to someone for some purpose, either orally or in writing.

b. No single methodology or fixed set of techniques is prescribed.

c. It is essential that learners be engaged in doing things with language that is, that they use language for a variety of purposes in all phases of learning.

Additionally, discussion and debating activities also include problem-solving skill. Hutchinson and Waters (1987) see learners as thinking beings, and they call this theory of learning a Cognitive Code where problem-solving task is the basic teaching technique.

Referring to the objectives in the previous sub-section, I found three relevant features and one shortcoming regarding language learning philosophy in the syllabus. First, the five goals arranged in the syllabus focus on the expressions and rules understanding in discussion and debate. This is compatible with one of the CLT principles that "...speakers communicate about something to someone for some purpose..." (Berns, 1990:104). The multiple purposes from 
the syllabus can be seen from the objectives such as "giving commentary", "getting people's attention and interrupting " when involving in discussion activity. Second, the teaching methodologies used are not single, "discussion, role playing, dialogue-making and debating", which are also in with the CLT principle. Teaching methodology will be specifically discussed in the next sub-section. Third, discussion and debating activities enable the students to work in group, and therefore, the students can practice the language (L1) through discussing a topic. This is appropriate with the CLT principle. However, since problem-solving is the root skill in discussion and debating activities, problem-solving task is needed (Hutchinson \& Waters, 1987). In discussing and debating a topic, functional language is not enough. Critical thinking plays important role in it.

Although CLT is appropriate with the syllabus goals, Cognitive Code is also required to meet the compulsory needs in discussion and debate that is problem-solving task (Hutchinson \& Waters, 1987). For example, at the end of the course, the students are able to build outstanding arguments, logic justification, and find solution. I propose this theory to be used in the syllabus not for a hundred percent, but probably forty or thirty percent of the overall course. Therefore, the syllabus will not only centre on the functional language and discussion and debating rules, but the students' critical thinking is also sharpened.

\section{Methodology}

Methodology refers to "carefully considered theory of learning or it can simply be used to refer to a classroom technique for an activity" (Donna, 2000:69). With that in mind, then teaching methodology reflects the language learning theories used. Concerning the CLT and Cognitive Code used in the syllabus, the teaching methodologies used should be based on these two theories' principles. Since CLT focuses on meaning in communication (Savignon, 1991), and leaners are engaged in doing things with language (Berns, 1990), the teaching methodologies arranged should centre on students' activeness. Hutchinson and Waters (1987:118-130) suggest eight principles of learning-centred methodologies that enable learners' activeness as follows:

a. Second language learning is a developmental process.

b. Language learning is an active process.

c. Language learning is a decision-making process.

d. Language learning is not just a matter of linguistic knowledge.

e. Language learning is not the learners' first experience with language.

f. Learning is an emotional experience.

g. Language learning is to a large extent incidental.

h. Language learning is not systematic.

\begin{tabular}{|c|}
\hline LEARNING METHODS \\
\hline Discussions, role play, dialogue-making, debating practices \\
\hline
\end{tabular}

The syllabus applies various types of methodologies: discussion, role-play, dialoguemaking and debating. Besides being appropriate with the CLT principle (Berns, 1990), these different methodologies in different times will maximise the learning and accommodate learners' different styles of learning (Donna, 2000). Discussion activity enables students to "exchange information, opinions or comments or to formulate sentences which have meaning" (op cit.:71). "Role-play involves simulated real-life language use" (op cit.). Dialogue is focused conversation, engaged in intentionally with the goal of increasing understanding, addressing problems, and questioning thoughts and actions (Romney, 2015). Hence, dialogue-making is 
an activity of creating a focused conversation. Debating is a clash of arguments, and it seeks to explore the reasons behind each side (Wirawan, 2010).

While discussion and debating methodologies satisfy the all Hutchinson's and Waters' (1987) eight principles of learning-centred methodologies, I will criticize role-play and dialogue-making in some points. To perform in a role-play, students normally prepare their dialogue using manuscript. In addition, it is also an acting. Furthermore, dialogue-making is an activity of creating a dialogue. Although it is later performed, it is a manuscript making activity. With those in mind, I argue that role-play and dialogue-making do not encourage students' 'incidental communication' (op cit.). These two methodologies do not also contain 'a decision-making process' (op cit.) that are very crucial discussion and debating activities. Therefore, if I am requested to change this methodology part, I will not put role-play and dialogue-making teaching methodologies as the mainstay and not put them in the same level as that of discussion and debating as described in the syllabus. Role-play and dialogue-making seem more appropriate used in situational communication or Speaking in semester 1 in my institution. Discussion and debating activities should reflect on the students' 'real ability'. However, role-play, dialogue-making and also games can be used for trivial activities in the classroom.

\section{Materials Used and Resources}

"Materials are any systematic description of the techniques and exercises to be used in classroom teaching" (Brown, 1995:139). He adds that this "can accommodate books, packets of audiovisual aids, games or any of other myriad types of activities that go on in the language classroom (op cit.). Hutchinson and Waters (1987:108) suggest a materials design model, which is then called materials criteria, which consists of four elements:

a. Input: a text, dialogue, video-recording, diagram or any piece of communication data.

b. Content focus: language is not an end itself, but a means of conveying information and feelings about something.

c. Language focus: the ultimate purpose of language learning is language use.

d. Task: the aim is to enable learners to use language and provide them necessary language knowledge.

Furthermore, Stevick (1971, cited in Brown, 1995:160) suggests that materials should be evaluated in terms of qualities, dimensions, and components as follows:

a. Three qualities: strength, lightness, transparency (as opposed to weakness, heaviness, opacity)

b. Three dimensions: linguistic, social, topical

c. Four components: occasions for use, sample of language use, lexical exploration of structural relationships. 


\begin{tabular}{|c|c|}
\hline MATERIALS USED & RESOURCES \\
\hline $\begin{array}{l}\text { Asking for and providing meaning and } \\
\text { clarification, Asking about/expressing } \\
\text { opinions, Giving commentary, Getting } \\
\text { people's attention and in ter r u p ting, } \\
\text { Checking, understanding/clearing up } \\
\text { misunderstanding, Chairing a discussions and } \\
\text { meetings, Technique of debating } \\
\text { Debating system, and Debating system in } \\
\text { Australasian parliamentary system, British } \\
\text { parliamentary system and Asian parliamentary } \\
\text { system }\end{array}$ & $\begin{array}{l}\text { 1. Matreyek, W. 1983. Communicating in } \\
\text { English: Examples and models 2: situation } \\
\text { (17-31) } \\
\text { 2. http://www.actdu.org.au/archives/actein } \\
\text { site/basicskills.html } \\
\text { 3. http://iteslj.org/Techniques/Krieger-Debate. } \\
\text { html } \\
\text { 4. http://www.brethrenassembly.com/Ebooks/ } \\
\text { Apol_18A1.pdf } \\
\text { 5. http://en.wikipedia.org/wiki/Australia-Asia } \\
\text { debate } \\
\text { 6. http://en.wikipedia.org/wiki/British_ } \\
\text { Parliamentary_Style } \\
\text { 7. http://flynn.debating.net/ }\end{array}$ \\
\hline
\end{tabular}

While the materials are in line with the objectives, of all elements in the syllabus, resources are the weakest part with several reasons. First, the input (Hutchinson \& Waters, 1987) used are one textbook and six website links which three of them are Wikipedia links. From the quality aspect, these resources are weak (Stevick in Brown, 1995) because the only textbook used is an old publishing that is in 1983. This will not be problematic if it is accompanied by other more updated inputs. This book is also used in the previous semester module because this book is basically about situational communication which is too light (op cit.) to use in discussion and debating activities. Another weakness is that the dominant inputs are website links. I have researched three of them [http://www.actdu.org.au/archive/acteinsite/basicskills.html], [http:// iteslj.org./Techniques/Krieger-Debate.html] and [http://www.brethrenasseambly.com/Ebooks/ Apo1, $18 \mathrm{~A} 1 . p d f]$ but they cannot be found on the addresses. This makes both students and other lecturers difficult to find the materials. Besides, using more legitimate resources such as books, videos, and pictures is suggested (Crook, 2010). Using Wikipedia links is the next drawback. DSH (2008) remarks that Wikipedia is not necessarily valid in academic arena. Wikipedia also seems not provide complete information about a material.

As a result, I will propose three more appropriate handbooks. One of the books is entitled Debating Handbook (2010) compiled by Kementrian Pendidikan Nasional (National Education Ministry of Indonesia) which contains Asian Parliamentary Debating System. The second book is Panduan or Guidance of National University English Debating Championship (NUEDC, 2010) which elaborates British Parliamentary Debating System. The last one is MAD Member Training Handbook explaining Australasian Parliamentary Debating System, published by Monash Association of Debaters in 2010. These three books are very useful since they contain the definition of debate, how to build a good argument, aspects assessed, speakers' duties and scoring. They enable the students to use the language and achieve critical thinking. The discussion process is also in it. Hence, these books are compatible with Hutchinson's and Waters' (1987) materials design model on the input, content focus, language focus and task, and satisfy Stevick's (n Brown, 1995) quality which is strong. However, the existing book can still be used as one of the accompanying resources, not as the mainstay.

\section{Evaluation}

Evaluation is defined as "the systemic gathering of information for purposes of making decisions" (Richards et al., 1985:98). The gathering of information is the activity which Brown (1995) calls testing, and making decisions can be scoring. Brown (ibid.) introduces two types of testing as a course evaluation: Norm-Referenced Test (NRT) and Criterion-Referenced Test 
(CRT). NRT is a test which spreads students out along the continuum of general abilities or proficiencies (op cit.). It has leveling such as beginner, intermediate and advanced (op cit.). The real examples reflecting this type of test are IELTS, TOEFL and TOEIC. Whereas, CRT is a test which enables students to score 100 percent if they knew all materials having been taught (op cit.). A test in a classroom normally uses this type of test (op cit.). Meanwhile, Hughes (2003) differs tests between direct/indirect, discrete/integrative testing and subjective/ objective scoring. He elaborates that direct testing means texts and tasks should be authentic, while indirect one is measuring the students' abilities. Discrete testing is "when one element at a time is tested and integrative involves combining many language elements in the completion of a task" (p.16).

\begin{tabular}{|l|}
\hline EVALUATIONS \\
\hline Oral Tests \\
\hline
\end{tabular}

There is only one phrase of evaluation stated in the syllabus that is oral tests. It is true that a Speaking course is normally evaluated in oral or spoken tests. However, the syllabus designer did not elaborate how the oral test will be conducted. If the testing is evaluating discussion and debating, in what way are they assessed?

Since there is no further explanation of the oral tests, I will introduce my proposals. NRT (Brown, 1995) is a test type that can be used in this course because the students will be encouraged to achieve the maximum score, 100. I will also apply Hughes' (2003) idea about indirect testing since the purpose of the test is to measure the students' ability. The students' ability should meet the discussion and debating criteria. They are not only linguistic features such as pronunciation, vocabulary, grammar, but matter, manner, and method are also assessed. Thus, this is an integrative testing because it combines linguistic and non-linguistic elements (op cit.). To avoid subjective scoring (op cit.), I will use my own evaluation sheet, since the Department has not arranged standard scoring for Speaking courses, containing the criteria mentioned above. The score range is between 10 and 100 in each element, and the average score is then drawn. This shows fairness for the students because if they regularly come to the classes, read related references, and are highly motivated to practice in discussion and debating activities in the classroom, they will create high scores because what is tested has been given in the classroom.

\section{CONCLUSION}

The following is the summary of my stance and the changes that could be made of each element of the syllabus:

1. Although the debating systems seem not meet the School's vision that is to create professional teachers (FKIP UMS, 2015), I will support this course still taught at the Department due to $21^{\text {st }}$ century needs: critical thinking and problem solving. Because of these needs, it is required a high level of thinking and language proficiency. Therefore, I will put this course at the end of the Speaking syllabus continuum that is in Speaking 4 which is currently about presentations which are considered easier that discussion and debating.

2. In order the quality to achieve by the students to be clearer, I will add matter, manner and method to the objectives. The three debating systems are not given once in a meeting, but the objectives should clearly state particular meetings for a particular debating system. The objectives should be also put in the 'right' goals.

3. Besides CLT, I will propose Cognitive Code as the theory learning underlying the syllabus' goals. It provides problem-solving task (Hutchinson \& Waters, 1987) that fits in discussion 
and debating activities. Therefore, the students' critical thinking will be sharpened.

4. Role-play and dialogue-making methodologies should not become the mainstay as discussion and debating methodologies. Since role-play and dialogue-making tend to be acting activities and do not contain 'a decision-making process' (Hutchinson \& Waters, 1987), these methodologies are better applied in Speaking 1, Situational Communication.

5. Due to highly lack of the resources of materials, I will propose three debating handbooks: Debating Handbook (Kemdiknas, 2010), Guidance of NUEDC (Depdiknas, 2010) and MAD Member Training Handbook (MAD, 2010). These books have contained both discussion and debating skills.

6. To fulfil the 'unexplained' oral test provided in the syllabus, I will propose a combination of testing types by Brown (1995) and Hughes (2003). I will use CRT and Indirect testing types by using integrative criteria to assess the students' ability. The assessment sheet containing the criteria is also made to avoid subjective scoring.

7. Therefore, the answer of this research question whether the syllabus elements meet the students' needs is that some elements meet the students' needs, while some parts of the syllabus do not. However, the changes offered may help improve the syllabus.

\section{REFERENCES}

Berns, M.S. (1990) Contexts of Competence: Social and Cultural Consideration in Communicative Language Teaching. New York: Plenum Press.

Brindley, G. (1989) Assessing Achievement in the Leaner-Centered Curriculum. Sydney: National Center for English Language Teaching and Research.

Brown, J.D. (1995) The Elements of Language Curriculum. New York: Heinle and Heinle. Cator, K. (1011) The Department of Education's Karen Cator Answers Your Questions about the National EdTech Plan. Available from: http://www.edutopia.org/blog/karencator-doe-video-answers-questions-national-education-technology-plan [Accessed May 1st, 2015].

Celce-Muria, M. and Olshtain, E. (2000) Discourse and Context in Language Teaching: A Guide for Language Teachers. Cambridge: Cambridge University Press.

Crook, C. (2010) The "Digital Native" in Contexts: Tensions Associated with Importing Web 1.0 Practices into The School Setting. Available from: http:/www.nottingham.ac.uk/ [Accessed may $1^{\text {st }}, 2015$ ].

Depdiknas (2010) Panduan National University English Debating Championship (NUEDC). Jakarta: Direktorat Akademik.

Donna, S. (2000) Teach Business English. Cambridge: Cambridge University Press.

DSH (2008) Is Wikipedia Becoming a Respectable Academic Source? Available from: https://digitalscholarship.wordpress.com/1008/09/01/is-wikipedia-becoming-a respectable-academic-source/ [Accessed May 1 $\left.{ }^{\text {st }}, 2015\right]$.

Elmusharaf, K. (2012) Qualitative Data Collection Techniques. Geneva: RCRU.

Fisher, P. (1996) Designing a Seventh-Grade Social Studies Course for ESL Students at an International School. In K. Graves (ed.) Teachers as Course Developers. Cambridge: Cambridge University Press.

FKIP UMS (2015) Available from:http://fkip.ums.ac.id/ [Accessed May 1², 2015]. 
Graves, K. (2000) Designing language courses: A guide for teachers. London: Heinle \& Heinle. Hall, G. And Cook, G. (2011) Own-Language Use in Language Teaching and Learning, Language Teaching, 45(3), 171-308.

Hughes, A. (2003) Testing for Language Teachers. Cambridge: Cambridge University Press. Hutchinson, T. and Waters, A. (1987) English for specific purposes: A learning-centred approach. Cambridge: Cambridge University Press.

Kemdiknas (2010) Debating Handbook. Jakarta: Direktorat Pembinaan Sekolah Menengah Atas.

MAD (2010) MAD Member Training Handbook. Melbourne: MAD.

Mager, R.F. (1975) Preparing Instructional Objectives. Belmont, CA: Fearon-Pitman.

McKay, S. (1978) Syllabuses: Structural, Situational, National, TESOL Newsletter, 11(5), 11.

Nunan, D. (1993) Task-Based Syllabus Design: Selecting, Grading and Sequencing Tasks. In G, Crookes \& S.M. Gass (eds.) Tasks in a Pedagogical Context: Integrating Theory and Practice. Clevedon: Mulyilingual Matters Ltd.

Richards, J.C. et al. (1985) Longman Dictionary of Applied Linguistics. London: Longman.

Richards, J.C. (2001) Curriculum development in language teaching. Cambridge: Cambridge University Press.

Romney, P. (2015) The Art of Dialogue. Available from: https://www.clarku.edu/difficult dialogues/learn/index.cfm [Accessed May 1st, 2015].

Savignon, S.J. (1991) Communicative Language Teaching: State of the Art, TESOL Quarterly, $15(1), 1-7$.

Wirawan, D.I. (2010) Debating Handbook Debater. Available from: http://www/scribd.com/ doc/41161109/Debating-Handbook-Debater\#scribd [Accessed on May 1 ${ }^{\text {st }}, 2015$ ]. 